\title{
The Relationship Between Auditors Positions and Electronic Transformation in Auditors' Effectiveness
}

\author{
Tuba DERYA BASKAN ${ }^{\mathrm{iD}}$ a
}

aKırıkkale Üniversitesi, İktisadi ve İdari Bilimler Fakültesi- İşletme Bölümü, Kırıkkale, Türkiye. tdbaskan@gmail.com

\begin{tabular}{ll}
\hline ARTICLE INFO & ABSTRACT \\
\hline Keywords: & $\begin{array}{l}\text { Purpose - Information users who are able to reach the firms' information want the } \\
\text { E-transformation }\end{array}$ \\
Anova & $\begin{array}{l}\text { needed, and to be transparent and clear. For this reason, the results of independent } \\
\text { audit reports are crucial for the information users. On the other hand, auditing firms } \\
\text { Tukey Test }\end{array}$ \\
would also aim to reach transparent and quick information by using electronic \\
transformation elements. Supervisors can also use e-transformation elements to \\
access information that is quick and easy to control. \\
Received 3 October 2018 & $\begin{array}{l}\text { Design/methodology/approach - A survey was applied to the independent audit firms } \\
\text { in Ankara and Anova and Tukey tests were conducted. }\end{array}$ \\
Accepted 15 March 2019 & $\begin{array}{l}\text { Findings - At the end of the study, a meaningful relationship was found between the } \\
\text { title of employees in the audit body and the elements of e-transformation in audit } \\
\text { activity. } \\
\text { Discussion - Electronic transformation elements that are important in every } \\
\text { Research Article }\end{array}$ \\
company in both the public and private sectors are also important in audit firms and \\
their necessity is increasing.
\end{tabular}

\section{1- INTRODUCTION}

With the rapid development of information technology in the world at the beginning of the 20th century, the knowledge production process has been accelerated by computers. Companies started to use information technologies in their operations and started to use these technologies in almost all of their departments such as marketing, management, finance and accounting. This process, known as the electronic business, has affected all the firms' departments. At this point, accounting practices have also changed and electronic transformations have also started to be applied in accounting rapidly.

The authority responsible for the regulation of electronic transformation in Turkey has been effective in transition to electronic accounting processes with the Ministry of Finance as the Revenue Administration (IOP). The Ministry of Finance about the electronic transformation authority regulations in Turkey is the Presidency of Revenue Administration (IOP). Article 242 (2) of the Tax Procedural Code (VUK) has defined the electronic book and electronic document, electronic record. In the same paragraph of the same article, the disclosure, recording, preservation and transmission of electronic books, documents and records has been explained.

The Turkish Commercial Code (TTK) has made the legal regulations regarding the number 6102 in article 64, paragraph second [It is obligatory to keep any kind of document, photocopy, carbon copy, microfiche, computer recording or similar copy in the written, visual or electronic form, submitted in connection with its operation] ( TPL Item 242, 2.paragraph).

After these explanations, it is possible that e- transformation is defined as "an accepted change process in the use of information technologies" (Çetiner 2009, p.40). It is expressed as the fact that e- transformation information technologies are developed and firms can perform their activities on the electronic medium in

\section{Suggested Citation:}

Derya Baskan, T. (2019). The Relationship Between Auditors Positions and Electronic Transformation in Auditors' Effectiveness, Journal of Business Research-Turk, 11 (1), 114-119. 
order to adapt to this change. Firms also use many electronic transformation elements such as e-registration, e-signature, e-billing, e-confirmation, e-signature, e-archive and so on. Accounting is not only a unit for firms to register their money inputs and outputs but also to be a source of quality, fast, accurate and reliable information for audit activity in financial reporting period.

Due to these developments in accounting profession, different specialization areas have been revealed, the need for personnel who are open to new improvements and changes has increased, and the profession has become a priority and the need for managers' vision to be wide has arisen. Because accounting records at firms is not only about keeping records and showing company performance, but also it is important since it is guiding information users. Especially after the Enron and its successive accounting scandals, regulatory authorities in charge of accounting have reorganized and put into practice.

In this point both internal and external audit factors play an active role in firms. Arens and Loebbecke (1991, pp.3-4) describe the most general definition of auditing as follows: the reports submitted regarding the company's activities and events comply with predetermined conditions, the collection of records, the examination and the submission of reports to information users. Gücenme $(2204,2)$, it was stated that the resentment was a comparative process and that generally accepted accounting principles should be applied in order to make the comparison.

Audit firms should adapt to this electronic transformation process, and company employees should be open to newness and awareness of this issue. The government also imposed legal obligations on companies in order to make it easier for them to keep their accounting records, make their activities faster, and obtain more reliable information. Within the scope of E-transformation, the knowledge, skills and expertise of the employees in the company gain importance and it is aimed to use the electronic transformation process more easily with the training programs.

In this framework, it is aimed to measure the effectiveness of the audit aimed at using the electronic transformation elements in the control of the accounting activities and the employees' titles. In the later part of the work, the opinions about the electronic transformation in the literature related to the topic were evaluated and then the survey study was done about the topic.

\section{2- LITERATURE}

There is a serious number of research related to electronic transformation elements in the literature. In the world, the increase of technological developments since the beginning of the 2000s has also increased the globalization process and it continues to take its place more in the literature. In the study, we have given weight on the works that put emphasis on the importance of electronic transformation elements. When it comes to international literature; the existence of electronic records in supervision, the necessity of using accounting package programs, Kaufman and Schmidt (1957:33) worked and reached the conclusion that the firm would change the success and the workflow in the company. When the time of Kaufman and Schmidt's study is thought, it can be determined that the importance of accounting package programs have been recognized long before. Bhimani (2003) examined the use of audit support systems with a study that emphasizes the importance of technological innovations.

Accordingly, audit firms have determined that the use of these support systems is technology applications that facilitate control and accelerate auditing. At the same time, he emphasized the need for incentives for the use of audit support systems. Wood and Sangster (2002: 669) conducted a study that measures the necessity of employees to keep up with technological developments. They stated that the working environment has changed with the elements of e-transformation. Therefore, they have argued that the awareness of individuals should be increased.

In Turkey, progress has been made in the transformation process as a result of extensive studies carried out by the Ministry of Finance Revenue Administration. When we look at the national literature, we see that papers related to this issue are important both in the public and in congresses and councils as well as academia. Çetin (2010) states that the intensive use of electronic data can be easily accessed and the works can progress faster. Erol and Subaşı (2015) stated that electronic transformation elements change account definition of accountants not only to keep records but also play a part in evaluating and designing this system. Kıvanç et al. (2006) emphasized the importance of firms playing an active role in the e- 
transformation process and the necessity of overcoming critical factors in order for the e- transformation process to be successful. Moreover, they pointed out that it is important to look at this subject from the fact that the managers have extensive authority over the firms in the e- transformation process. Because the managers have a big share in the decisions made in the firms, the vision of the managers in the electronic transformation process is important. On the other hand, they pointed out that the size of the company operates in a harder process than the small firm in decision making, which in turn affects this transformation process. They also emphasized that the infrastructure system is also important in companies and the number of experts and competent people who can use the transformation elements will increase the success in the company transformation process. In the process of e- transformation of Tektüfekçi (2017), Turkey tried to determine the extent to which the web-based research result in the beginning of the process was increasing day by day. According to this, in order for the application to be successful in Turkey, it is necessary to use smart devices such as computers, tablets, etc. and determine the software programs correctly.

There have been some studies of state institutions with the electronic transformation process which is progressing rapidly in our country since the beginning of 2000's. The rapid development of information technologies has started the process of keeping up with this structure. Our modern processing country started the process of storing, using information in computtransformationer environment in many public institutions together with Electronic transformation (e- transformation) Turkey Project in 2003.

In this way, information is transmitted easily and quickly, and retrospective controls are starting to be done easily. E-transformation has started to be used in many areas such as education, business, service sector, and has made it easier to access information. The State Planning Organization (SPO) has done a serious work on this subject by publishing "Turkey's Information Society Conversition Policy". According to this, the e transformation on process is defined as [a country that has become a focus point in science and technology production uses information and technology as an effective tool, generates more value through information based decision making processes, and has a global competitiveness and a high level of prosperity] (SPO, 2003). In order to make effective use of information and communication technologies in Turkey in 2004-2005, studies were conducted covering 2006-2010 periods in order to utilize information and communication technologies effectively.

The Turkish e- transformation Project, with the Ninth Development Plan covering 2007-2013 periods, emphasizes the importance of information transformation and constitutes the most comprehensive period in this issue. In this way the awareness of the programs implemented up to this point has been increased to enable the emergence of programs that can be implemented in public and private sectors. At the same time comparative analyzes made at national and international levels have started to measure the extent to which the objectives of the transformation process are reached (kalkınma bakanligi.org.tr.; dpt.org.tr).

Since this process is the most important users of enterprises, citizens and the state, this study examines the potential of Turkey to transform into information society in the framework of technological developments in 2010. The aim of this study is to develop the skills of processing and operating employees to use the technology, to make modern business processes in enterprises and to maximize the use of technological developments by the firms. According to the research conducted, the use of customer relationship management practices in Turkey in the period of 2007-2010 increased from 8.7 percent to 32.6 percent, the use of supply chain management practices increased from 5.6 percent to 16 percent and the application of enterprise resource planning use rose from 7.8 percent to 15.3 percent. E-signature usage rate for enterprises with 10 or more employees was 10.1 percent in 2010. It is emphasized that e-commerce needs to be developed in order to catch up with these developments, and it is emphasized that firms should support and encourage firms to increase the security of e-signatures.

\section{3- DATA AND ANALYSIS METHOD}

In determining the relationship between the title of the employees of the audit companies and the use of electronic transformation elements in the audit activity, a questionnaire was applied to the independent audit institutions operating in Ankara. There are 42 independent audit companies in Ankara. The contact information of 2 of these companies could not be reached. Over 40 audit firms of which 27 have been reached and the survey questions have been answered. This survey was prepared by conducting a literature search and statistical analyses were carried out on the reliability of the survey. The reliability of the scale was 
tested using the Cronbach Alpha coefficient method (Tavakol and Dennick, 2011:53) and the scale was found to be " $85 \%$ very good". The survey consists of 27 questions; the first four questions are regulated by variable demographic characteristics, and the other 22 questions were prepared by triple likert scale.

After the reliability of the scale became very high, a questionnaire was made in the audit institutions. SPSS 20.0 package program was used in the analysis of the questionnaire data. As a result of the analysis, Anova and ukey tests were done and the relationships between the results were examined.

- According to the demographic characteristics of the companies participating in the survey, the operation years of the companies with less than 2 years is 5 , the age with $2-5$ years is 9 , the age with $5-10$ years is 5 and the age with 10 years or more is 7 .

- Six of the survey institutions participating in the survey do not use e-confirmation elements. - On the other hand, all the supervisory firms think that technological use is necessary in the long run.

- 14 auditing firms answered that electronic transformation increased the reliability; 12 of them responded etransformation increased their reliability partially while 1 of them mentioned e-transformation has not affected their reliability.

- 15 of the audit firms said that electronic transformation made easier the audit activity and 12 of them told that it was partially facilitated the auditing. There were no audit firms that says e-transformation did not made easier auditing.

- It has been determined that measures have been taken in order to prevent errors that may occur in the control activities in electronic environment conducted by most companies.

- Electronic transformation elements in accounting records are important in terms of evaluating, correcting and increasing the quality of auditing firms.

- Electronic transformation applications such as e-billing, e-registration, e-archive, e-ledger are required. Successful implementation of these applications has been noted by most firms, which has affected the success of supervisory firms.

After using the electronic transformation elements of the companies and determining the duration of activity, the distribution of the titles of the employees of the company that forms the basis of the work was determined. This result is shown in the following table.

Table 1: Employees' Business Position In The Firm

\begin{tabular}{|l|c|c|}
\hline & Frequency & Cumulative Percentage (\%) \\
\hline Responsible Lead Auditor & $\mathbf{1 4}$ & $\mathbf{5 1 , 9}$ \\
\hline Lead Auditor & $\mathbf{3}$ & $\mathbf{6 3 , 0}$ \\
\hline Auditor & $\mathbf{8}$ & $\mathbf{9 2 , 6}$ \\
\hline Assistant Auditor & $\mathbf{2}$ & $\mathbf{1 0 0 , 0}$ \\
\hline Total & $\mathbf{2 7}$ & \\
\hline
\end{tabular}

The responsibilities of the respondents in the firm are composed of 14 responsible lead auditors, 3 lead auditors, 8 auditors and 2 auditor assistants. When the distribution of the titles of the participants in the survey was examined, it was determined that the majority of the respondents were high level auditors. After the universe distributions in the analysis, it is aimed to use the electronic transformation process according to these titles. Our hypothesis in this point also works in the following way.

$\mathrm{H}_{0}$ : There is a meaningful relationship between the title of the employees in the auditing institution and the elements of electronic transformation in the efficiency of auditing.

Our constructed hypothesis was analyzed in detail by the Turkey test and the following table is shown. 
T. Derya Baskan 11/1 (2019) 114-119

Tablo 2: Hypothesis Conclusion

\begin{tabular}{|l|c|c|}
\hline Employees' Situation In The Firm & \multirow{2}{*}{ Subset for alpha $\mathbf{0 . 0 5}$} \\
\cline { 3 - 3 } & & $\mathbf{1}$ \\
\hline Responsible Partner Lead Auditor & $\mathbf{3}$ & $\mathbf{1 , 0 0}$ \\
\hline Lead Auditor & $\mathbf{8}$ & $\mathbf{1 , 0 0}$ \\
\hline Auditor & $\mathbf{2}$ & $\mathbf{1 , 0 0}$ \\
\hline Assistant Auditor & $\mathbf{1 4}$ & $\mathbf{1 , 1 4}$ \\
\hline Sig. & & $\mathbf{8 8 4}$ \\
\hline
\end{tabular}

The table above also explains the use of electronic transformation elements according to the company's ownership distributions. According to this, it is revealed that the effectiveness of auditing firms in the audit institution using the title of the employees and the elements of the e- transformation increases. Our hypothesis was accepted at the level of $5 \%$ significance level.

It has been determined that many firms such as e-registration, e-signature, e-declaration, e-archive are used in firms and serious infrastructure studies are conducted in this regard as a result of the inspection conducted in audit firms in Ankara. It was found that firms using e-transformation factor had more confidence and increased the quality of audit reports. It has also been determined that these e-confirmation elements must be equipped with innovations, and have broad vision management. At the same time, it was determined that those who will use these elements should be able to keep up with technological developments and be open to this issue. The hypothesis was confirmed that the purpose of the study was "a meaningful relationship between the title of the employees in the auditing institution and the elements of electronic transformation", and as the titles of employees in the company increased, it was determined that the records of the companies were more easily reached with electronic transformation and that the consistency was more accurate and complete information was reached. The fact that information is complete, consistent and open requires institutionalization principles. In this sense, the institutionalization of firms is considered by auditors who will be better equipped with electronic developments and use more effectively.

\section{4- CONCLUSION}

It is inevitable that businesses that do not follow up the developments in information technology will lose their power in the globalization process. In this process, it is necessary for companies to closely follow developments in international platforms and studies are carried out on this subject. This process removes geographical boundaries and provides easy archiving and retrieval of information. Firms from technological developments take advantage of the fact that information is kept for a long time and information can be reached quickly. At the same time it is easier to compare the information and it is thought that this process can provide the work force savings. The vision of the electronic confirmation process requires a wide range of managers and employees in order to require a certain cost and a certain training process during the creation of the infrastructure system. This process has also taken place in the audit firms, where trainings and symposiums have been increased and work has begun to ensure that they are implemented quickly.

The firms with the creation of numerous information and documents on each and every day, companies need to be able to easily access this information and documents, to ensure their reliability and to maintain them for long periods of time. With the rapid development of technology, companies have started to adopt and use electronic transformation elements such as e-registration, e-archive, e-declaration, e-confirmation, esignature and e-billing in order to adapt to these changing condition.

The study is shaped by whether the electronic transformation elements used by the independent audit firms during the financial reporting audits increase the audit and how these transformation elements change as the company employees' titles increase. Accordingly, it is determined that audit firms make their audits more effective and quality by using electronic data, and this is supported by the number of employees in audit firms. In this sense, electronic transformation elements that are important in every company in both the public and private sectors are also important in audit firms and their necessity is increasing. In the light of accounting scandals experienced as a result of corruption and misinformation in firms, environments should be created in order to implement the electronic transformation elements that have an important role 
T. Derya Baskan 11/1 (2019) 114-119

in correcting the deteriorating system, and the availability of these elements should be increased and supported through trainings.

\section{KAYNAKÇA}

Altunışık Remzi, Coşkun Recai,Bayraktaroğlu Serkan and Ylıdırım, Engin, Sosyal Bilimlerde Araştırma Yöntemleri SPSS Uygulamalı, Sakarya Kitapevi, 7.Baskı, 2012.

Arens Alvin and Loebbecke James, Accounting:An Integrated Approach Prentice Hall International Edition, 5.Publisher, 1991.

Bantin, Phillip C. “The Indiana University Electronic Records Project”. The American Archivist, 62( 1), 1999, pp.153-163.

Bhimani, Alnoor, Management Accounting in the Digital Economy. Oxford, U.K.: Oxford University Press, 2003.

Çağıl Gültekin and Ergün Kadriye, "Geleneksel İşletme Anlayışından E-İ̇sletme Anlayışına Geçişte Yaşanan Problemler". Akademik Bilişim, 2008, pp.545-559.

Dowling, Carlin: "Appropriate Audit Support System Use: The Influence of Auditor, Audit Team, and FirmFactors". The Accounting Review,8 4(3), 2008, pp. 771-810.

Erol Meral. F. And Subaşı Şerife, “Türkiye de Muhasebe Öğretim Elenmanlarının Sayısal Çağda Teknoloji Kullanımına İlişkin Durum Tespiti.". Journal of the Institute of Social Sciences, 6(1), 2015, pp.85-112.

Gücenme Ümit, Muhasebe Denetimi , Bursa : Aktüel Yayın Dagıtım, 2004.

Kaufman Felix and Schmidt Leo A., “Auditing Electronic Records”. American Accounting Association, 32(1), 1957, pp:33-41.

Kernis, M. H., Cornell, D. P., Sun, C. R., Berry, A., Harlow, T., Bach, J. S. “ There's more to self-esteem than whether it is high or low: The importance of stability of self-esteem", Journal of Personality and Social Psychology, 65, 1993, 1190-1204.

Orhunbilge Neyran, Albayrak S. Aliand Bayyurt Nizamettin. Uygulamalı Çok Değişkenli İstatistik Teknikleri. İstanbul: Avcıol Basım Yayın. 2006.

Wood Frank and Sangster Alan, Business Accounting 2, London:Prentice Hall, 2002.

Tavakol, Mohsen / Dennick, Reg. “Making sense of Cronbach's Alpha”. International Journal of Medical Education International, 2, 2011, pp. 53-55.

Tektüfekçi, Fatma. “E-Dönüşüm Sürecinde E-Muhasebe Uygulamaları: Türkiye Örneği”. Bilgi Ekonomisi ve Yönetimi Dergisi. 12(1), 2017, pp. 79-88.

TC Kalkınma Bakanlığı, E-Dönüşüm Türkiye Projesi, http://www.Bilgitoplumu.Gov.Tr/Documents/1/Diger/BtsVeEylemPlanıNıhaiDegerlendırmeRaporu.P df, Erişim Tarihi: 24.01.2018, 1-206.

TC Devlet Planlama Teşkilatı Müsteşarlığı Bilgi Toplumu Dairesi Başkanlığı, DPT Yayın http://www.bilgitoplumu.gov.tr/Documents/1/Diger/Bilgi_Toplumu_Istatistikleri_2011.pdf, No:2826, Erişim Tarihi: 02.02.2018. 